\title{
Endoscopic Resection of a Large Colonic Lipoma: Case Report and Review of Literature
}

\author{
Girolamo Geraci Franco Pisello Enrico Arnone \\ Antonio Sciuto Giuseppe Modica Carmelo Sciumè
}

Section of General and Thoracic Surgery, Division of Surgical Endoscopy, University of Palermo School of Medicine, Palermo, Italy

\section{Key Words}

Colonic lipoma $\cdot$ Endoscopic resection $\cdot$ Literature review

\begin{abstract}
Colonic lipomas are uncommon, benign, submucosal adipose tumors that are usually asymptomatic. Large lipomas can cause symptoms such as constipation, abdominal pain, rectal bleeding and intussusception. We report the case of a 60-year-old man with a history of lower abdominal pain and pseudoobstructive symptoms. Colonoscopy revealed a large polypoid sessile lesion in the sigma. We used a standardized technique of polypectomy, preceded by submucosal injection of dilute $5 \mathrm{ml}$ polygelin with epinephrine 1:10,000 solution, to fully resect large colonic lipomas. The lipoma size was $3.5 \mathrm{~cm}$. No bleeding or perforation developed. Histology showed the polyp to be a submucosul lipoma. On follow-up, there was no residual lesion. Colonic lipomas larger than $2 \mathrm{~cm}$ can be safely and efficaciously removed using electrosurgical snare polypectomy technique. The technique of submucosal injection before resection and using an electrocautery snare appears to be safe and reduces the risk of perforation reported in the literature.
\end{abstract}

\section{Introduction}

Colonic lipomas are benign adipose tumors that are rarely symptomatic and are usually detected incidentally during colonoscopy; they are the second commonest benign tumor of the large bowel. In general, small colonic lipomas rarely cause symptoms and are usually detected incidentally at colonoscopy, surgery, or autopsy. On the contrary, large lipomas can cause serious symptoms. This is a report of endoscopic removal of a large colonic lipoma. 


\begin{tabular}{r|l|l|l} 
Case Reports $h$ & Case Rep Gastroenterol 2010;4:6-11 & Published online: February 3, 2010 & $\begin{array}{l}\text { ○ 2010 S. Karger AG, Basel } \\
\text { ISSN 1662-0631 } \\
\text { Www.karger.com/crg }\end{array}$ \\
& & & \\
\hline
\end{tabular}

\section{Case Report}

A 60-year-old man presented for colonoscopy after a 1-year history of lower abdominal pain and pseudoobstructive symptoms. His mother developed colorectal cancer at 69 years of age. Personal medical history included hypertension managed with a thiazide diuretic. Physical examination of the abdomen and digital rectal examination were both unremarkable.

The patient drank the prescribed $4 \mathrm{l}$ of propylene ethylene glycol solution the night before surgery. At colonoscopy under analgosedation (Olympus CF-Q160 video colonoscope), a $35 \mathrm{~mm}$, smooth, soft, round, semipedunculated (pseudopedicle, with wide base) mass was found in the sigmoid colon. The tumor was compressible when a biopsy specimen was taken ('cushion sign'). Two huge vessels were identified within the stalk of this lesion. The mass was submucosal and had a yellowish hue. The decision was made to remove it endoscopically.

After written informed consent, the lipoma was removed using a standard snare (ConMed Singular Polypectomy Snare, type Medium Crescent, USA) and electrocautery with blended monopolar current, after injection of the base with $5 \mathrm{ml}$ polygelin with epinephrine 1:10,000 solution (injection-assisted polypectomy techniques). There was no bleeding from the polypectomy site and the patient tolerated the procedure without any sequelae. He was discharged $48 \mathrm{~h}$ after the procedure, asymptomatic, on a short course of oral antibiotics (metronidazole $500 \mathrm{mg}$ a day for 5 days) to prevent postpolypectomy syndrome.

On microscopic examination, the tumor was covered by normal mucosa and had uniform parenchyma in bright yellow color; blood vessels were found within the tumor, which consisted largely of typical lipocytes and numerous fibra intervals, resulting in lobulated appearance of the lipoma in the absence of fat necrosis, granulation or ulceration, thus confirming the diagnosis of colonic lipoma. The patient was negative at 6 months follow-up (fig. 1).

\section{Discussion}

Lipomas are benign, nonepithelial tumors that occur throughout the gastrointestinal tract albeit predominantly in the colon. Although they constitute $2.6-4 \%$ of benign neoplasms of the gastrointestinal tract, they are the second commonest benign tumor of the large bowel $(0.2-26 \%)$. They are more frequent in the colon (64\%) than in the stomach or the small bowel; the right colon and the ileocecal valve are frequent sites. Generally, there is only a solitary lesion, but multiple localizations have been reported in $5-10 \%$ of cases. The tumor appears as a well-delineated, soft, ovoid, yellowish mass, originating from the submucosa in $90 \%$ of cases, and can be sessile or pedunculated. Superficial ulcerations have been described, making the colonoscopic diagnosis somewhat difficult. The median age at the time of diagnosis ranged from 50 to 69 years; in surgical series, it is 1.5-2 times more common in women, but in endoscopic series there are not differences in sex prevalence [1]. The incidence of colonic lipoma in autopsy series ranges from 0.035 to $4.4 \%$ [2].

Transformation to liposarcoma is exceedingly rare, described in only a few case reports [3], but colonoscopic examination may reveal an ulcerated fungating mass that appears grossly malignant; the spiculated appearance of the surface of the mass may be due to inflamed and/or ulcerated lipomatous tissue [4]. In general, colonic lipomas do not cause symptoms and are usually detected incidentally at colonoscopy, surgery, or autopsy. The symptoms are not related to the involved segment of large bowel. Generally, a lipoma of less than $2 \mathrm{~cm}$ is usually asymptomatic, whereas $75 \%$ of lipomas exceeding $2 \mathrm{~cm}$ in diameter (size appears to correlate with symptoms) present with symptoms such as pain (55\%), diarrhea, intermittent subacute obstruction of the colon, bleeding from the ulcerated tip of the lesion (40\%) and may be the lead point for intussusceptions (5-7\% in patients with large lipomas) [5]. 
The definitive diagnosis is only endoscopic (barium enema is aspecific for round and regular filling defects). The characteristic findings include the mucosa being elevated over the lipoma with the biopsy forceps ('tent sign'), indentation of the lipoma with the biopsy forceps (so-called 'cushion sign' or 'pillow sign'), or the 'naked fat sign' where the fat can be extruded after removal or serial biopsy [6]. Surgical or endoscopic removal is indicated for such lesions [7]. Tamura et al. [8] have suggested that lipomas greater than $20 \mathrm{~mm}$ in diameter should be resected surgically. They also advocate utilizing magnifying videoscopy and endoscopic ultrasonography to aid in diagnosis. A detailed endoscopic examination of the base of the lesion is necessary (magnifying videoscopy and endoscopic ultrasonography are proposed) to decide whether endoscopic resection is possible (histopatholgy on all lipomas that resulted in perforation contained portions of muscularis propria and serosa invaginated into the pedicle). Actually, however, the indication of endoscopic resection of colonic lipoma is still a subject of controversy. Endoscopic removal of large colonic lipomas is technically difficult because of their vascular nature, large pedicle, and size [7]. However, endoscopic removal of lipomas 2$4 \mathrm{~cm}$ or greater in diameter has been associated with a high risk of perforation [9], and is associated with increased morbidity compared with retrieving adenomatous polyps, probably because fatty tissue does not conduct electricity well and increasing the power to assist the completion of the polypectomy leads to increased heat production and damage to the adjacent bowel wall with subsequent perforation (lipomatous tissue contains a lower water content and therefore conducts electrosurgical current less efficiently) [5].

Chase and Yarze [10] suggest that endoscopic ultrasound (EUS) could be used to determine whether the stalk of a lipoma contains serosal elements. After our anedoctal experience and by reviewing the international literature, we believe that the risk for perforation with large pedunculated lipomas is overstated and that the use of EUS routinely in these lipomas is unjustified: the current data show that, when clinically indicated, endoscopic removal of large ( $>2 \mathrm{~cm}$ in diameter) pedunculated colonic lipomas is safe when snare electrocautery is applied utilizing careful endoscopic technique. There are numerous reports of large lipomas ranging from 2 to $11 \mathrm{~cm}$ in diameter being resected during colonoscopy without complications [11]. In the case of small pedunculated lipomas, there is no increased risk of removal compared to pedunculated adenomatous polyps [12]. With large lipomas, the size of the stalk is of greater importance than the diameter of the lipoma itself when considering endoscopic removal. The diameter of the tissue area (i.e. stalk) being transected with the snare should be sufficiently narrow to allow complete transection. The endoscopist can readily determine the feasibility of endoscopic removal by assessing the thickness of the stalk around a closed snare. A careful assessment of snare placement ensures that only the stalk is involved and will prevent the inadvertent application of cautery through lipomatous tissue. By following these guidelines, pedunculated lipomas both 1 and $3 \mathrm{~cm}$ in diameter may be safely removed endoscopically without the added cost of evaluation by EUS. However, injection of saline solution or a saline solution of epinephrine into the submucosa beneath the lesion creates a 'cushion' between the lesion and the muscularis propria, thereby reducing the risk of perforation [7]. There are also reports in the literature of about 20 cases of spontaneous expulsion of the lipoma per rectum as a result of self-amputation for spontaneous necrosis as it twists on its pedicle or slippage of the lipoma from a tear at the base of the mucosal layer overlying it [13] (table 1).

Endoloop ligation of colonic lipomas appears to be a promising new technique in the management of patients with large colonic lipomas who are otherwise referred for surgery to avoid the high risk of perforation associated with snare cautery. Further validation of this technique is required; by using the 'ligate and let go' technique (without endoscopic 
resection), endoloops have been successful in the management of masses arising from the muscularis propria (big and long stalk) [14]. Sessile or broad semipedunculated lesions preclude endoloop placement. If the pedicle is $4 \mathrm{~mm}$ or less in diameter, the loop cannot be tightened sufficiently to ensure hemostasis; it is doubtful that a loop is useful in this situation. Also, for extremely broad semipedunculated or sessile lesions, closure of the loop beneath the planned resection margin may be impossible (the intended resection margin may lie beneath the loop closure) [15]. If there is a large visible blood vessel in the stalk, then placing a hemoclip before or after polypectomy is possible to decrease postprocedure bleeding [5].

\section{Conclusions}

Colonic lipomas are benign and typically incidentally diagnosed during colonoscopy. In the case of small pedunculated lipomas, there is no increased risk of removal compared to pedunculated adenomatous polyps. We believe that endoscopic removal of colonic lipomas larger than $2 \mathrm{~cm}$, even if is technically difficult because of their vascular nature, large pedicle, and size, is safe, feasible and effective using standard polypectomy technique with the availability of endoloop (in case of long stalk) and hemoclips (in case of bleeding) in case of uneventful complications or to prevent them.

Table 1. Endoscopic/perendoscopic resection of colonic lipomas: literature review

\begin{tabular}{|c|c|c|c|c|c|c|}
\hline First author & Case & Injection & Other tools & Location & Diameter & Complications \\
\hline $\begin{array}{l}\text { Bar-Meir, } \\
1981[20]\end{array}$ & 1 & epinephrine solution & snare & left colon & $5 \mathrm{~cm}$ & - \\
\hline $\begin{array}{l}\text { Pfeil, } \\
1990[6]\end{array}$ & 7 & NR & NR & NR & $1.9-4.2 \mathrm{~cm}$ & 3 perforation \\
\hline $\begin{array}{l}\text { Stone, } \\
2001[11]\end{array}$ & 17 & NR & snare & NR & $2-11 \mathrm{~cm}$ & 3 perforation \\
\hline $\begin{array}{l}\text { Tamura, } \\
2001[8]\end{array}$ & 1 & epinephrine solution & snare & left colon & $4.5 \mathrm{~cm}$ & - \\
\hline $\begin{array}{l}\text { Kim, } \\
2002[7]\end{array}$ & 4 & $\begin{array}{l}\text { saline solution (2) } \\
\text { epinephrine solution (2) }\end{array}$ & snare & $\begin{array}{l}\text { left colon }(2) \\
\text { right colon }(2)\end{array}$ & $0.8-3.8 \mathrm{~cm}$ & - \\
\hline $\begin{array}{l}\text { Abe, } \\
2004 \text { [16] }\end{array}$ & 2 & epinephrine solution & snare & $\begin{array}{l}\text { left colon (1) } \\
\text { ileocecal valve (1) }\end{array}$ & $\begin{array}{r}2 \mathrm{~cm} \\
1.5 \mathrm{~cm}\end{array}$ & - \\
\hline $\begin{array}{l}\text { Raju, } \\
2005 \text { [17] }\end{array}$ & 1 & no injection & $\begin{array}{l}4 \text { loops for } \\
\text { autoamputation }\end{array}$ & right colon & $4 \mathrm{~cm}$ & - \\
\hline $\begin{array}{l}\text { Murray, } \\
2005 \text { [18] }\end{array}$ & 3 & no injection & loops + snare & $\begin{array}{l}\text { left colon (2) } \\
\text { right colon (1) }\end{array}$ & $2.6-3.5 \mathrm{~cm}$ & - \\
\hline $\begin{array}{l}\text { Wild, } \\
2008 \text { [19] }\end{array}$ & 1 & NR & $\begin{array}{l}2 \text { colonoscopy, piecemeal } \\
\text { with snare, } 8 \text { clips, } 2 \text { loop }\end{array}$ & left colon & $8 \mathrm{~cm}$ & - \\
\hline $\begin{array}{l}\text { Martin, } \\
2008[4]\end{array}$ & 1 & epinephrine solution & snare & right colon & $7 \mathrm{~cm}$ & - \\
\hline $\begin{array}{l}\text { Kaltenbach, } \\
2008[14]\end{array}$ & 8 & no injection & $\begin{array}{l}\text { 1-2 loops for } \\
\text { autoamputation }\end{array}$ & $\begin{array}{l}\text { left colon (5) } \\
\text { right colon (3) }\end{array}$ & $2.5-6 \mathrm{~cm}$ & $\begin{array}{l}1 \text { incomplete } \\
\text { resection }\end{array}$ \\
\hline
\end{tabular}

$\mathrm{NR}=$ Not reported 


\begin{tabular}{r|l|l|l} 
Case Reports in & $\begin{array}{l}\text { Case Rep Gastroenterol 2010;4:6-11 } \\
\text { D0I: 10.1159/000260053 }\end{array}$ & Published online: February 3, 2010 & $\begin{array}{l}\text { @ 2010 S. Karger AG, Basel } \\
\text { ISSN 1662-0631 } \\
\text { www.karger.com/crg }\end{array}$ \\
\hline
\end{tabular}

Fig. 1. Endoscopic resection of colonic lipoma: endoscopic appearance (a); 'tenting effect' (b, c); 'cushion sign' (d); injection and snare polypectomy $(\mathbf{e}, \mathbf{f})$; result of polypectomy $(\mathbf{g})$; specimen (h); 6 months follow-up (i).

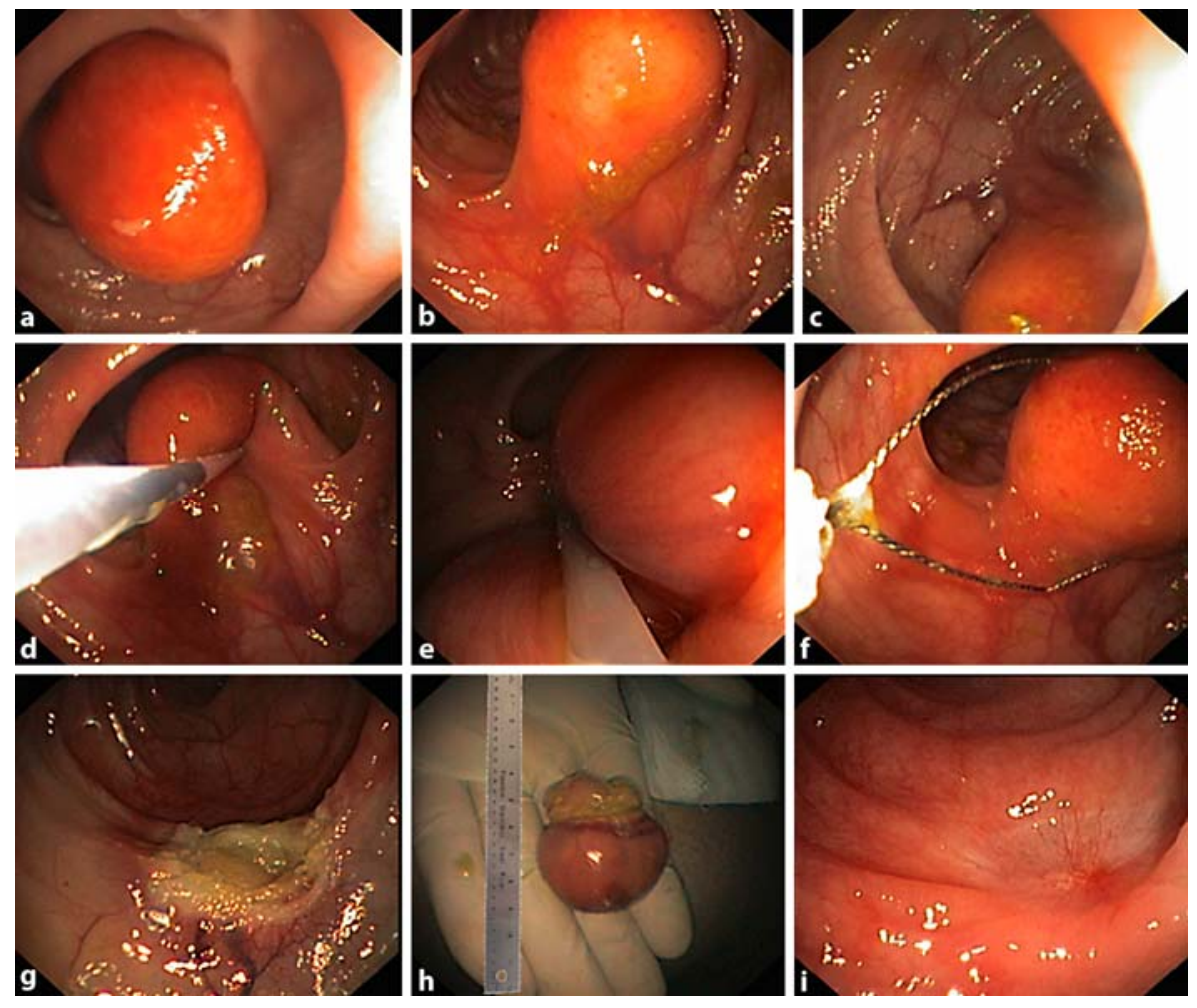




\section{References}

1 Nebbia JF, Cucchi JM, Novellas S, Bertrand S, Chevallier P, Bruneton JN: Lipomas of the right colon: report on six cases. Clin Imaging 2007;31:390-393.

2 Ryan J, Martin JE, Pollock DJ: Fatty tumours of the large intestine: a clinicopathological review of 13 cases. Br J Surg 1989;76:793-796.

-3 Gutsu E, Ghidirim G, Gagauz I, Mishin I, Iakovleva I: Liposarcoma of the colon: a case report and review of literature. J Gastrointest Surg 2006;10:652-656.

4 Martin P, Sklow B, Adler DG: Large colonic lipoma mimicking colon cancer and causing colonic intussusception. Dig Dis Sci 2008;53:2826-2827.

5 Bahadursingh AM, Robbins PL, Longo WE: Giant submucosal sigmoid colon lipoma. Am J Surg 2003;186:81-82.

6 Pfeil SA, Weaver MG, Abdul-Karim FW, Yang P: Colonic lipomas: outcome of endoscopic removal. Gastrointest Endosc 1990;36:435-438.

7 Kim CY, Bandres D, Tio TL, Benjamin SB, Al-Kawas H: Endoscopic removal of large colonic lipomas. Gastrointest Endosc 2002;55:929-931.

8 Tamura S, Yokoyama Y, Morita T, Tadokoro T, Higashidani Y, Onishi S: 'Giant' colon lipoma: what kind of findings are necessary for the indication of endoscopic resection? Am J Gastroenterol 2001;9:1944-1946.

\9 Bar-Meir S, Halla A, Baratz M: Endoscopic removal of colonic lipomas. Endoscopy 1981;13:135-136.

10 Chase MP, Yarze JC: 'Giant' colonic lipoma - to attempt endoscopic resection or not? Am J Gastroenterol 2000;95:2143-2144.

$\checkmark 11$ Stone C, Weber HC: Letters to the editor: endoscopic removal of colonic lipomas. Am J Gastroenterol 2001;96:1295-1296.

12 Christie JP: The removal of lipomas. Gastrointest Endosc 1990;36:532-533.

13 Sidani SM, Tawil AN, Sidani MS: Extraction of a large self-amputated colonic lipoma: a case report. Int J Surg 2008;6:409-411.

14 Kaltenbach T, Milkes D, Friedland S, Soetikno R: Safe endoscopic treatment of large colonic lipomas using endoscopic looping technique. Dig Liver Dis 2008;40:958-961.

15 Matsushita M, Hajiro K, Takakuwa H, Kusumi F, Maruo T, Ohana M, Tominaga $\mathrm{M}$, Okano A, Yunoki Y: Ineffective use of a detachable snare for colonoscopic polypectomy of large polyps. Gastrointest Endosc 1998;47:496-499.

16 Abe T, Kawai N, Tanabe J, Wada S, Okada A, Meren H, Masuzawa M, Tsujimoto M, Kawano S: Pedunculated colonic lipoma. Gastrointest Endosc 2004;60:259260.

17 Raju GS, Gomez G: Endoloop ligation of a large colonic lipoma: a novel technique. Gastrointest Endosc 2005;62:988-990.

18 Murray M, Kwan V, Williams SJ, Bourke MJ: Detachable nylon loop assisted removal of large clinically significant colonic lipomas. Gastrointest Endosc 2005;61:756-759.

19 Wild D, Fiore J, Guelrud M: Successful endoscopic resection of a giant colonic lipoma causing intussusceptions. Gastrointest Endosc 2008;68:774-775.

20 Bar-Meir S, Halla A, Baratz M: Endoscopic removal of colonic lipoma. Endoscopy 1981;13:135-136. 